\title{
A NEW SPECIES OF CHOMELIA (RUBIACEAE, GUETTARDEAE) FROM THE BRAZILIAN PLANALTO
}

\author{
PIERO G. DELPRETE \\ Federal University of Goiás, Campus II, Institute of Biological Sciences, \\ Department of General Biology, ICB-1, 74001.970 Goiânia, Goiás, Brazil. \\ Current address: Institut de Recherche pour le Développement - AMAP, TA-A51/PS2, \\ Blvd de la Lironde, 34398 Montpellier Cedex 5, France; \\ e-mail: pdelprete@hotmail.com
}

\section{SUMMARY}

During the ongoing treatment of the Rubiaceae for the Flora of the states of Goiás and Tocantins and the Flora of the Federal District of Brazil, a new species of Chomelia (C. kirkbridei Delprete) from the Brazilian Planalto was found, and is here described and illustrated. A key to the species of Chomelia occurring in the states of Goiás and Tocantins and the Federal District of Brazil, is also included.

Key words: Guettardeae, Rubiaceae, Chomelia, Federal District, Goiás, Brazil, South America, floristics, taxonomy.

\section{INTRODUCTION}

Chomelia Jacq., as traditionally recognized, is a Neotropical genus of about 70-80 species of shrubs and trees (Andersson 1992, Govaerts et al. 2008), with the main centres of diversity in the Andean Cloud forests, Guayana Highlands and the Brazilian Atlantic forest. In addition, Chomelia has been classically treated as the sister genus of Guettarda L., distinguished by the persistent, lobed calyx (vs caducous, truncate to shallowly lobed in Guettarda), corolla lobes valvate or valvate-induplicate (vs imbricate), and fruits usually 2-locular (vs (1-2-)3-9-locular) (Hooker 1873, Müller Argoviensis 1881, Bremekamp 1934, Steyermark 1972, 1974). The molecular phylogenies produced by Achille et al. (2006) showed that Chomelia is instead more closely related to Stenostomum C.F.Gaertn. than to Guettarda. Stenostomum is a genus of c. 47 species, centred in the Caribbean Region (Govaerts et al. 2008), that was represented in the phylogenetic study only by $S$. acutatum DC. and $S$. myrtifolium Griseb.). Of the genus Chomelia, only $C$. ribesioides Benth. ex A.Gray and C. spinosa Jacq. were included, which provided preliminary evidence that Chomelia and Stenostomum are sister taxa; however, because only two species of Chomelia were investigated, the monophyly of the two genera was not significantly tested. Chomelia is here treated as traditionally delimited. 


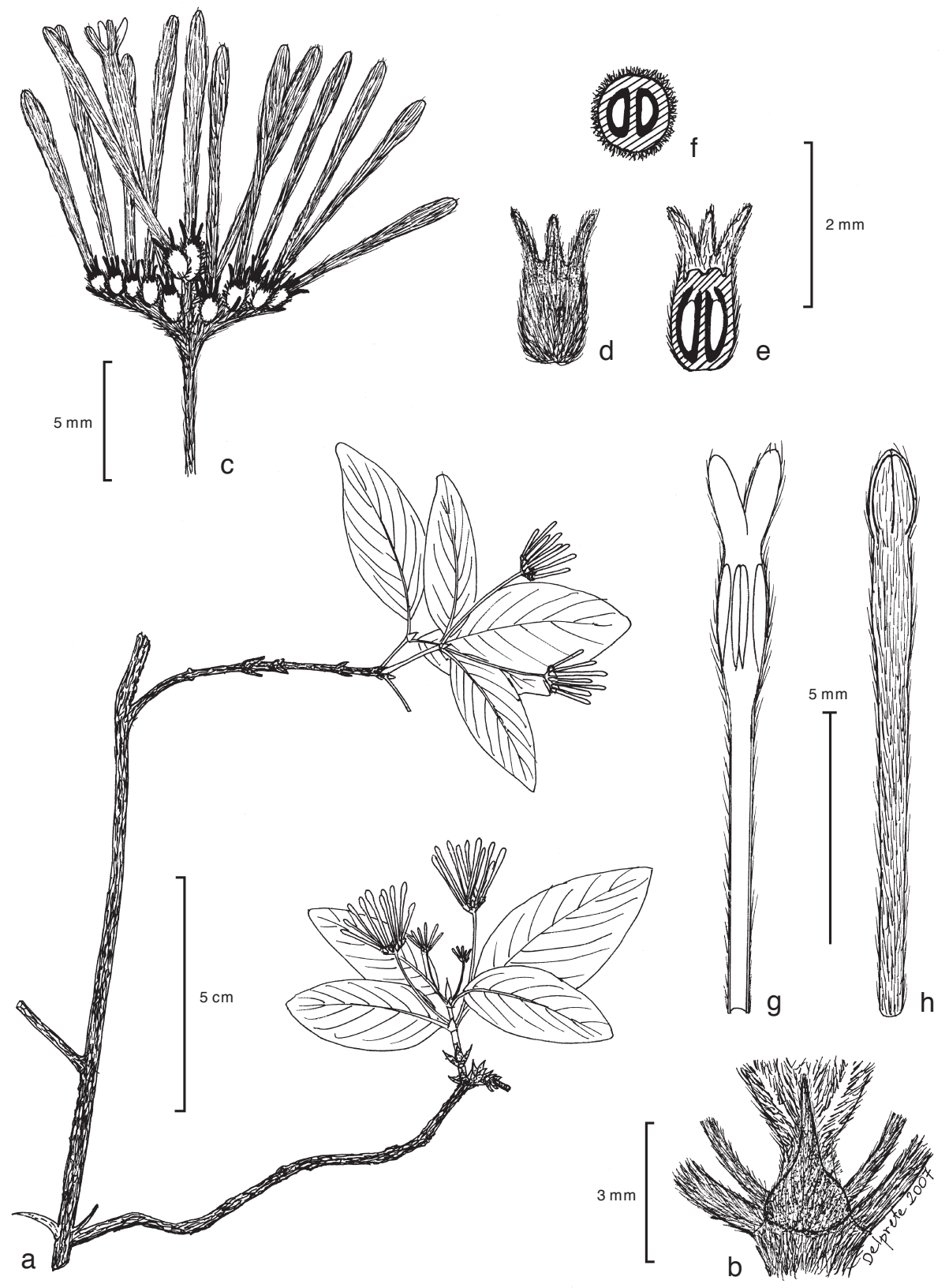

Fig. 1. Chomelia kirkbridei Delprete. a. Habit of flowering branch; b. node with stipule, base of two peduncles and young petioles; c. detail of one inflorescence; d. hypanthium and calyx, side view; e. hypanthium and calyx, longitudinal section; f. hypanthium and ovary, cross section; g. corolla in anthesis longitudinally dissected; $h$. flower bud, side view, note that the two facing lobes are slightly shorter (from J.H. Kirkbride 3628). 


\section{CHOMELIA}

Chomelia has never been subject of a taxonomic revision; however, a few floristic treatments are available for the identification of South American species. Steyermark (1967) treated Chomelia for the Flora of the Guayana Highlands (and contiguous areas, in fact the treatment included north-eastern Brazil and the northern portion of the Brazilian Shield), where he recognized 11 species. More recently, Taylor \& Steyermark (2004) studied this genus for the Flora of the Venezuelan Guayana (states of Amazonas and Bolívar), where they recognized nine species. As for Central-Western Brazil, there is no Rubiaceae treatment available, and the most recent floristic treatment that includes this area dates back to the Flora Brasiliensis (Müller Argoviensis 1881). A preliminary synopsis of the Rubiaceae of the states of Mato Grosso and Mato Grosso do Sul was compiled by Delprete \& Cortes-B. (2007), where seven species of Chomelia are listed. The Rubiaceae contributions for the Flora of the states of Goiás and Tocantins (Delprete in prep. a) and the Federal District of Brazil (Delprete in prep. b) will be completed in the near future. So far, in the states of Goiás and Tocantins, and in the Federal District, five species of Chomelia have been found: C. obtusa Cham. \& Schltdl., C. parviflora (Müll.Arg.) Müll.Arg., C. pohliana Müll.Arg., C. ribesioides, and C. kirkbridei, described below.

\section{Chomelia kirkbridei Delprete, spec. nov. — Fig. 1}

Chomelia polyanthae Blake (Colombia, Venezuela) simillimus inflorescentiis axillaribus pedunculatis condensatis, sed ab illa differt foliis domatiis destitutis (nec foliis domatiis trichomatosis instructis), pedunculis parce patenter pubescentibus vel breviter lanatis (nec pedunculis glabris), calyce tubo deminuto usque as $0.4 \mathrm{~mm}$ longo, vel nullo, atque lobis 4-8 mm longis (nec tubo $1.5-1.8 \mathrm{~mm}$ longo ac lobis $0.7-1 \mathrm{~mm}$ longis), corolla extus parce antrorse pubescente tubo 10-12 mm longo atque lobis 1.3-1.7 mm longis (nec corolla extus dense strigulosa tubo $8-15 \mathrm{~mm}$ longo atque lobis 3-4 mm longis). - Typus: J.H. Kirkbride 3628 (holo UB; iso NY, UB, US n.v.), Brazil, Federal District, near Rio das Salinas, $15^{\circ} 31^{\prime} \mathrm{S}, 47^{\circ} 57^{\prime} \mathrm{W}, 770 \mathrm{~m}, 8$ Oct. 1980 (fl).

Tree to $5 \mathrm{~m}$ tall; branchlets pale brown-greyish, sparsely lenticellate; axillary thorns slightly curved, $3-8 \mathrm{~mm}$ long. Stipules ovate-triangular, $2.5-4.5$ by $2.3-3 \mathrm{~mm}$, acute to short-acuminate at apex, adpressed-sericeous outside when young, turning glabrate at a later stage, persistent, sometimes irregularly breaking off at older nodes. Petioles 2-8 $\mathrm{mm}$ long, spreading or adpressed-pubescent; blades ovate, elliptic to obovate, 1.5-5 by $0.8-3.2 \mathrm{~cm}$, acute, obtuse to round at base, obtuse to acute at apex, chartaceous, drying reddish brown above and greyish olive green below, sparsely puberulent above (velutinous to the touch), densely spreading pubescent below; secondary veins 6 each side, sparsely to densely pubescent above, densely spreading pubescent below; margins thickened, ciliate; domatia absent. Inflorescences axillary, condensed cymes, 7-30-flowered; peduncles filiform, 1-3.5 cm long, sparsely spreading-pubescent to short-lanate. Flowers hermaphroditic, sessile, subtended by two narrowly-lanceolate, oblong to linear bracteoles $0.3-0.6 \mathrm{~mm}$ long, free at base; hypanthium ellipsoid, $0.7-1 \mathrm{~mm}$ long, densely adpressed-pubescent; calyx tube extremely reduced or absent, to $0.4 \mathrm{~mm}$ long, sparsely puberulent to short-pubescent, lobes usually unequal, ovate, oblong-lanceolate to linear, $4-8$ by $0.2-0.4 \mathrm{~mm}$, acute at apex; corolla hypocrateriform, $12-14 \mathrm{~mm}$ long, 
tube green with white lobes, tube narrowly cylindrical, 10-12 mm long, gradually wider towards the mouth, $0.2-0.3 \mathrm{~mm}$ wide at base, $0.7-0.9 \mathrm{~mm}$ wide at mouth, sparsely antrorse-pubescent outside, glabrous inside, lobes (3 or) 4, narrowly imbricate, equal or slightly unequal, oblong-ovate, $1.3-1.7$ by $0.7-1 \mathrm{~mm}$, obtuse to round at apex, sparsely antrorse-pubescent outside (glabrous near margins), anthers included, subsessile, inserted $2-2.5 \mathrm{~mm}$ below the mouth, narrowly oblong, $1.1-1.3$ by $0.2 \mathrm{~mm}$, dorsifixed near the base, round at apex, short-caudate at base. Ovary 2-locular. Style included, 4.5-5 mm long, glabrous; style branches 2, unequal, narrowly oblong, the longer one c. $1 \mathrm{~mm}$ long, the shorter one c. $0.7 \mathrm{~mm}$ long. Fruit unknown.

Distribution \& Ecology - At the moment, only known from the type collection from the Federal District of Brazil, according to the label locally quite common, and found on calcareous outcrops at the border of deciduous forest, near Rio das Salinas. A trip in search for this species was realized in February 2008, at the type locality and surrounding region, but without success, indicating that it might be a rare and probably endangered taxon.

Etymology - The specific epithet is dedicated to Joseph H. Kirkbride Jr., renowned Rubiaceae specialist and generous colleague, who collected the type specimens when he was working at the University of Brasília.

Notes - Chomelia kirkbridei is most similar to Chomelia polyantha (from Colombia and Venezuela), because of the pedunculate, condensed, axillary inflorescences, thin peduncles, and oblong-ovate corolla lobes, from which it can be distinguished by the lack of leaf domatia (vs leaf domatia as tufts of hairs in C.polyantha), peduncle sparsely spreading-pubescent to short-lanate (vs glabrous), calyx tube extremely reduced or absent, to $0.4 \mathrm{~mm}$ long, and lobes $4-8 \mathrm{~mm}$ long (vs tube $1.5-1.8 \mathrm{~mm}$ long and lobes $0.7-1 \mathrm{~mm}$ long), corolla sparsely antrorse-pubescent outside, tube 10-12 $\mathrm{mm}$ long and lobes $1.3-1.7 \mathrm{~mm}$ long (vs densely strigillose outside, tube 8-15 $\mathrm{mm}$ long and lobes 3-4 mm long), and anthers basally caudate (vs round at base, not caudate).

Among the species of Chomelia occurring in the states of Goiás and Tocantins and the Federal District of Brazil, C. kirkbridei is most similar to C. obtusa (widespread throughout South America) by having corollas hypocrateriform and 12-14 mm long, from which it could be distinguished by the stipules $2.5-4.5 \mathrm{~mm}$ long (vs $0.7-1 \mathrm{~mm}$ long in C. obtusa), leaf blades sparsely to densely pubescent above and densely spreading pubescent below, without domatia (vs glabrous above and glabrous or sparsely pubescent below, with tuft-domatia), inflorescences 7-30-flowered (vs 1-3(-4)-flowered), corolla lobes narrowly imbricate, oblong-ovate, $1.3-1.7 \mathrm{~mm}$ long (vs lobes valvate, ovate to round, $1.5-2.5 \mathrm{~mm}$ long), and style included, 4.5-5 $\mathrm{mm}$ long (vs exserted, 9.5-13 mm long).

\section{KEY TO THE SPECIES OF CHOMELIA \\ IN THE STATES OF GOIÁS AND TOCANTINS AND THE FEDERAL DISTRICT (BRAZIL)}

1a. Corolla hypocrateriform, with tube $9-13 \mathrm{~mm}$ long ............. 2

b. Corolla narrowly-campanulate to campanulate, with tube $2.5-5 \mathrm{~mm}$ long . . . 4 
2a. Leaf blades $3-10.5$ by $1.5-5.5 \mathrm{~cm}$, acute to acuminate at apex, sericeous-pubescent or hispid below, with (6-)7-11 secondary veins each side; inflorescence laxely cymose, (14-)24-55-flowered; corolla lobes oblong-ovate to lanceolate, 3.5-4.5 $\mathrm{mm}$ long, corniculate, valvate-induplicate in bud .......... pohliana

b. Leaf blades $1.3-5(-6)$ by $0.5-3.5 \mathrm{~cm}$, obtuse to round at apex, glabrous or pubescent below, with 4-6 secondary veins each side; inflorescence constricted cymose, 1-3(-4)-flowered or 7-30-flowered; corolla lobes ovate to round, $1.3-2.5 \mathrm{~mm}$ long, not corniculate, valvate or narrowly-imbricate in bud . . . . . . . . 3

3a. Stipules 2.5-4.5 mm long; leaf blades sparsely to densely-pubescent above, densely patent-pubescent below; domatia absent; inflorescence 7-30-flowered; corolla lobes narrowly-imbricate in bud; style included, 4.5-5 mm long (calcareous outcrops) $\ldots \ldots \ldots \ldots \ldots \ldots \ldots \ldots \ldots \ldots \ldots \ldots \ldots \ldots \ldots \ldots \ldots \ldots \ldots \ldots$. kirkbridei

b. Stipules $0.7-1 \mathrm{~mm}$ long; leaf blades glabrous above and glabrous or sparsely-pubescent below; domatia as tufts of hairs; inflorescence 1-3(-4)-flowered; corolla lobes valvate in bud; style excluded, $9.5-13 \mathrm{~mm}$ long . . . . . . . . . obtusa

4a. Leaf blades glabrous below; inflorescence 1-5(-6)-flowered (white sand areas)

C. parviflora

b. Leaf blades villose, tomentose, velutinous, densely adpressed-, erect- or spreadingpubescent below; inflorescence 7-15-flowered (cerrado vegetation) . . . . . . . .

C. ribesioides

\section{ACKNOWLEDGEMENTS}

The project for the Rubiaceae treatments for the Flora of the states of Goiás and Tocantins (Delprete in prep. a), and Flora of the Federal District of Brazil (Delprete in prep. b) was realized during a fellowship for Visiting Scientist from the National Counsel of Technological and Scientific Development of Brazil (Conselho Nacional de Desenvolvimento Científico e Tecnológico - CNPq; grant 309885/2003-5), at the Federal University of Goiás, Goiânia, Brazil. My gratitude goes to Vera Lúcia Gomes-Klein (UFG) for the coordination of the project. This project was realized also through major loans (c. 4,000 specimens) from IBGE, NY and UB to UFG, for which the generous support of these institutions is kindly acknowledged. I am also grateful to the directors and curators of the following herbaria for loan of material and/or for providing working space during my several visits: HTO, IBGE, INPA, K, MBM, MG, MO, NY, P, R, RB, U, UB, US, and VEN. I am particularly grateful to Lubbert Westra $(\mathrm{U})$ for the Latin diagnosis and careful revision of the final draft of the manuscript.

\section{REFERENCES}

Achille, F., T.J. Motley, P.P. Lowry II \& J. Jérémie. 2006. Polyphyly in Guettarda L. (Rubiaceae, Guettardeae) based on ITS sequence data. Ann. Missouri Bot. Gard. 93: 106-124.

Andersson, L. 1992. A provisional checklist of Neotropical Rubiaceae. Scripta Bot. Belg. 1: 1-200.

Bremekamp, C.E.B. 1934. Rubiaceae. In: A. Pulle, Flora of Surinam, vol. 4: 113-298. De Bussy Ltd., Amsterdam.

Delprete, P.G. In prep. a. Rubiaceae. In: J. A. Rizzo (ed.), Flora dos Estados de Goiás e Tocantins-Coleção Rizzo. Universidade Federal de Goiás, Goiânia.

Delprete, P.G. In prep. b. Rubiaceae. In: T.B. Cavalcanti (Org.), Flora do Distrito Federal, Brasil. Embrapa Recursos Genéticos e Biotecnologia, Brasília.

Delprete, P.G. \& R. Cortés-B. 2007 ('2006'). A synopsis of the Rubiaceae of the states of Mato Grosso and Mato Grosso do Sul, central-western Brazil, with a key to genera, and a preliminary species list. Rev. Biol. Neotrop. 3: 13-96. 
Govaerts, R., D.G. Frodin, M. Ruhsam, D.M. Bridson \& A.P. Davis. 2008. A world checklist of Rubiaceae. www.rbgkew.org.uk/wcsp/rubiaceae (last accession on 29 February 2008).

Hooker, J.D. 1873. Tribus XIII. Guettardeae (Rubiaceae). In: G. Bentham \& J.D. Hooker, Genera Plantarum, vol. 2: 20-21, 99-104. Reeve \& Co., London.

Müller Argoviensis, J.J. 1881. Tribus II. Guettardeae (Rubiaceae). In: C.F.P. von Martius, A.G. Eichler \& I. Urban (eds.), Flora Brasiliensis, vol. 6, pars 5: 13-48, f. 2-6. Fleisher, Leipzig.

Steyermark, J.A. 1967. Chomelia. In: B. Maguire, J.J. Wurdack \& Collaborators, Botany of the Guayana Highlands - Part VII. Mem. New York Bot. Gard. 17: 333-341.

Steyermark, J. A. 1972. Guettardeae. In: B. Maguire, J.J. Wurdack \& Collaborators, Botany of the Guayana Highlands - Part IX. Mem. New York Bot. Gard. 23: 356-372.

Steyermark, J.A. 1974. Rubiaceae. In: T. Lasser \& J.A. Steyermark (eds.), Flora de Venezuela 9: 1-2070. Instituto Botánico, Caracas.

Taylor, C.M. \& J.A. Steyermark. 2004. Chomelia. In: J.A. Steyermark, P.E. Berry, K. Yatskievych \& B. K. Holst (eds.), Flora of the Venezuelan Guayana, vol. 8: 547-550. Missouri Botanical Garden Press, St. Louis, MO, USA. 